\title{
Identification of Human Sperm Antigens to Antisperm Antibodies*
}

CHI-YU GREGORY LEE, VINCENT LUM, ERIC WONG, ALAN C. MENGE, AND YUAN-SHEN HUANG

Department of Obstetrics and Gynaecology. The University of British Columbia, Vancouver. Canada IC.-Y.G.L., V.L., E.W.I, Department of

Obstetrics and Gynaecology, University of Michigan, Ann Arbor (A.C.M.), and Cancer Research Center, University of North Carolina. Chapel Hill

(Y.-S.H.)

ABSTRACT: We have successfully applied SDS (sodium dodecyl sulfate) gel/protein blot radioimmunobinding method to identify the molecular size of sperm antigens that elicit antisperm antibodies from patients with unexplained infertility. Following the transfer of renatured proteins from SDS gel of human sperm extract onto nitrocellulose strips, the radioimmunobinding was performed by incubating the strips with patients' sera at $1: 100$ dilution and then with $I^{125}$. labeled goat antihuman immunoglobulin G (IgG) or protein $A$ as detecting probes. Unique sperm antigens that reacted with some patients' sera were identified following the autoradiography of the incubated paper strips. Among the fifty-nine standard serum samples from the Reference Bank of the World Health Organization, about one-fourth of them were found to react predominantly with a sperm protein band having the reference value ( $R f$ value) of 0.2 and the approximate molecular weight of 90,000 dalton. A similar analysis was also performed with serum samples from vasectomized patients. Some of them also revealed a specific binding with the sperm antigen(s) of similar molecular weight. The results of this analysis were also compared with those of conventional tests for sperm antibodies as well as those of microplate radioimmunoassays and enzyme-linked immunoassays. This study suggests that SDS gel/protein blot radioimmunobinding method can be a useful tool for the molecular identification of unique human sperm antigen(s) that elicit naturally occurring antisperm antibodies in patients with unexplained infertility. (Am J Reprod Immunol. 1983; 3:183-187.)

Key words: Human sperm autoantigens, protein blot assays, antisperm antibodies, unexplained infertility

\section{INTRODUCTION}

It is commonly believed that autoimmune or isoimmune response to certain sperm antigens results in the production of antisperm antibodies in humans and in experimental animals. ${ }^{1-4}$ The presence of antisperm antibodies in sera and in reproductive tracts can cause agglutination and/or complement-dependent immobilization of spermatozoa in vitro or in vivo. This will in turn affect their fertilization capacity. ${ }^{5,6}$ The incidence of antisperm anti-

\footnotetext{
Submitted for publication August 13. 1982; accepted November 9. 1982

*This work was supported in part by Medical Research Council of Canada (grant 68 7707 ) and by British Care and Research Foundation (grant 65-4013). This work was presented at the Third Annual International Symposium on the Immunology of Reproduction, Winston-Salem. North Carolina, June 24-26, 1982

Address reprint requests to Dr. Chi-Yu Gregory Lee, F107, Andrology Laboratory. Acute Care Unit. The University of British Columbia. Vancouver, Canada V6T 2B5.
}

bodies in humans has been implicated to be associated with unexplained infertility. ${ }^{46}$ Conventionally, the presence of antisperm antibodies in humans is detected by bioassays such as Kibrick, ${ }^{7}$ Franklin-Dukes, ${ }^{8}$ and Isojima tests, ${ }^{9}$ for which donor's semen of high quality is required. However, these bioassays provide little information regarding the chemical and molecular nature of sperm antigens that elicit naturally occurring antisperm antibodies. Recently, Lee and his coworkers have successfully developed SDS gel/protein blot radioimmunobinding method for the molecular analysis of sperm antigens that react with antisperm antibodies from various sources, including those of human patients. ${ }^{10.11}$ Following gel electrophoresis, sperm antigens that have been separated according to their molecular size are renatured and transferred to nitrocellulose filters. A solid-phase radioimmunobinding method can be performed following the incubation with sera and then with $\mathrm{I}^{125}$-labeled antihuman IgG or protein A as detecting probes. The sperm antigens that react with antisperm antibodies can be revealed by autoradiography. This sensitive radioimmunobinding method enables us to resolve sperm antigens by their differential molecular weight and to detect those reacting with antisperm antibodies.

In this communication, attempts were made to analyze clinically defined serum samples including those from the Reference Bank of the World Health Organization and those of vasectomized patients. ${ }^{2}$ It is our contention that, with this sensitive assay procedure, one is able to classify the molecular patterns of sperm autoantigens or isoantigens that elicit naturally occurring antisperm antibodies in human patients.

\section{MATERIALS AND METHODS}

\section{Chemicals and Serum Samples}

Nitrocellulose sheets $(45-\mu \mathrm{m}$ pore size) were obtained from Millipore and protein A was obtained from Pharmacia. Goat antihuman IgG, chloramine $\mathrm{T}$, and sodium bisulfate were from Sigma. Horseradish peroxidase-labeled goat antihuman IgG was purchased from Kirkegaard and Perry Laboratories. $I^{125}$ (specific activity, 15 $\mu \mathrm{Ci} / \mu \mathrm{g}$ ) was from Amersham.

Fifty-nine standard serum samples (coded with serum numbers) were obtained from Dr. T. Hjort of the Reference Serum Bank of the World Health Organization (Institute of Medical Microbiology, University of Aarhus, Aarhus, Denmark). These are clinically defined serum samples, the titers of which have been previously determined by using the Franklin-Dukes and Isojima tests. ${ }^{8.9}$ Also analyzed were twenty-one serum samples from infertile men with spermagglutinating titers and thirteen serum samples from vasectomized patients of known history. ${ }^{2}$ 


\section{Iodination}

Protein A and goat antihuman IgG were labeled with $\mathrm{I}^{125}$ by using the chloramine $\mathrm{T}$ method of Greenwood and Hunter. ${ }^{12}$

\section{SDS Gel/Protein Blot Radioimmunobinding Method}

SDS (sodium dodecyl sulfate) gel/protein blot radioimmunobinding method employed in this study was performed according to procedure of Lee et al. ${ }^{10,11}$ Briefly speaking, the particulate fraction of human spermatozoa was first sonicated and solubilized in $1 \%$ sodium dodecyl sulfate. The solubilized sperm proteins were separated by vertically oriented slab gel electrophoresis using $10 \%$ acrylamide gel in the presence of $0.1 \%$ SDS. ${ }^{13}$ Following electrophoresis, the gel is placed in a renaturation buffer containing $4 \mathrm{M}$ urea for 4 to $6 \mathrm{~h}$ to ensure the removal of SDS. The renatured proteins that have been separated according to their molecular weights are transferred to nitrocellulose sheets in a transfer buffer by natural diffusion for 36 to $48 \mathrm{~h}$. The nitrocellulose sheets are cut into strips of $3-\mathrm{mm}$ to $5-\mathrm{mm}$ width. Following a short incubation with a blotting buffer containing $0.5 \%$ gelatin, the sera at 1:100 dilution are added to test tubes that contain strips in the same buffer for incubation of an additional 6 to $12 \mathrm{~h}$. $\mathrm{I}^{125}$-labeled protein $\mathrm{A}$ or $\mathrm{I}^{125}$-labeled goat antihuman IgG (about one $\mu \mathrm{Ci}$ per strip) are then added to each strip after removal of unreacted sera. Autoradiography is performed on an X-OMAT-AR-2 film (from Kodak) for 2 to $24 \mathrm{~h}$ of exposure prior to film development.

\section{Microplate Radioimmunoassays and Enzyme-Linked Immunoassays}

To compare the sensitivity of different methods for the detection of sperm antibodies in human patients, both microplate radioimmunoassays and enzyme-linked immunoassays were also employed in this study. These assays

\section{ANTI HUMAN IgG}

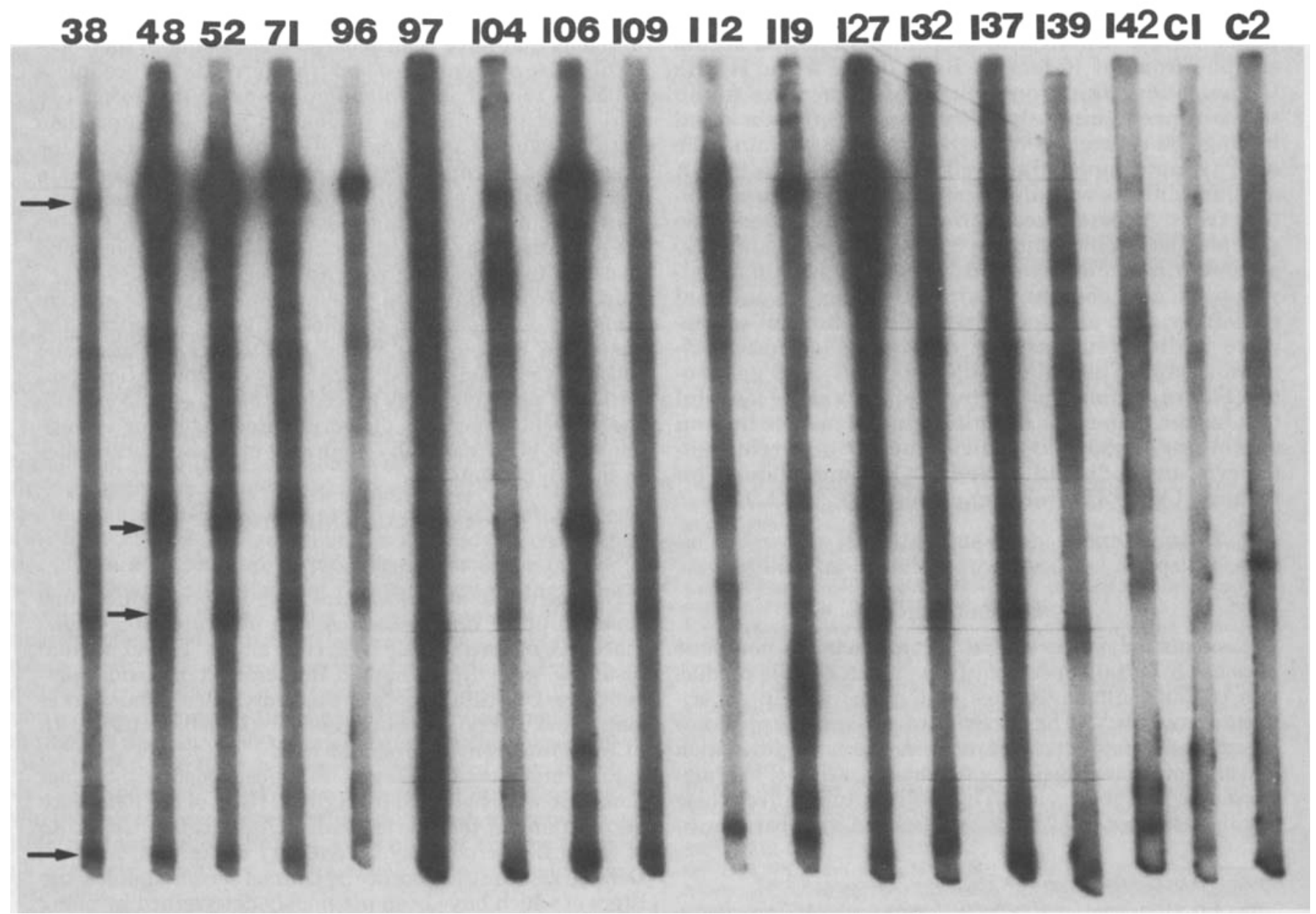

Fig. 1. Autoradiogram of nitrocellulose strips after radioimmunobinding with selected serum samples (\#38 to \#142) from Reference Bank of World Health Organization (serum dilution, $1: 100 ; 48$-h exposure). $\mathrm{C} 1$ and $\mathrm{C} 2$ are those of the serum sample from one of our patients who did not show the presence of antisperm antibodies by tray agglutination and by microsperm immobilization tests (serum dilution, 1:50 and 1:25 for $\mathrm{C} 1$ and $\mathrm{C} 2$, respectively). I $^{125}$-labeled antihuman IgG was used as a detecting probe. The frequently detected protein bands on strips are indicated by arrows. 
were performed according to the procedures of Voller et al. ${ }^{14} \mathrm{I}^{125}$-labeled goat antihuman IgG and peroxidase-labeled goat antihuman IgG were used as detecting probes, respectively, for these two assays. Briefly, to determine the relative titers of human serum antisperm antibodies, the particulate fraction of human spermatozoa was coated on the microplates (Immulon I, Dynatech Laboratories, Inc, Alexandria, $\mathrm{Va}) .{ }^{11}$

Human sera at 1:20 dilution in phosphate-buffered saline were incubated in wells of sperm-coated plates for 18 $h$ at $4^{\circ} \mathrm{C}$. In the case of radioimmunoassay, $\mathrm{I}^{125}$-labeled goat antihuman IgG was added to each well (about 0.1 $\mu \mathrm{Ci}$ per well) for one hour's incubation at $37^{\circ} \mathrm{C}$ following the removal of unbound sera. After incubation, the bound radioactivity in wells of microplates was determined by LKB $\gamma$-counter. For enzyme-linked immunoassay, peroxidase-labeled goat antihuman IgG was used instead as detecting probe. The color reaction associated with bound horseradish peroxidase was developed upon the addition of peroxidase substrates ${ }^{14}$ for 20 min. The optical density which determined the relative serum titers was measured by an automatic microplate reader at $492 \mathrm{~nm}$.

\section{Franklin-Dukes, Isojima, and Friberg Tests for Antisperm Antibodies}

For comparisons, the data regarding the titers of spermagglutinating and immobilizing antibodies for the W.H.O. standard serum samples were also provided by Dr. T. Hjort. They were determined by the procedures of FranklinDukes, ${ }^{8}$ Isojima, ${ }^{9}$ and Friberg (tray agglutination testTAT). ${ }^{15}$

\section{RESULTS AND DISCUSSION}

\section{Analysis of Serum Samples from the World Health Organization}

Among fifty-nine serum samples from the Reference Bank of the World Health Organization that were analyzed by SDS gel/protein blot radioimmunobinding method, the majority showed specific bindings to certain sperm antigens. To examine the consistency and specificity of binding between sperm antigens and antibodies, both $\mathrm{I}^{125}$-labeled antihuman IgG and $1^{125}$-labeled protein $A$ were used as comparative detecting probes. The results for the analysis of selected serum samples are shown in Figures 1 and 2,

\section{PROTEIN A}

\section{$384852719697 \quad 104 \quad 106109112$ I19 I27 I32 I37 I39 I42 CI C2}

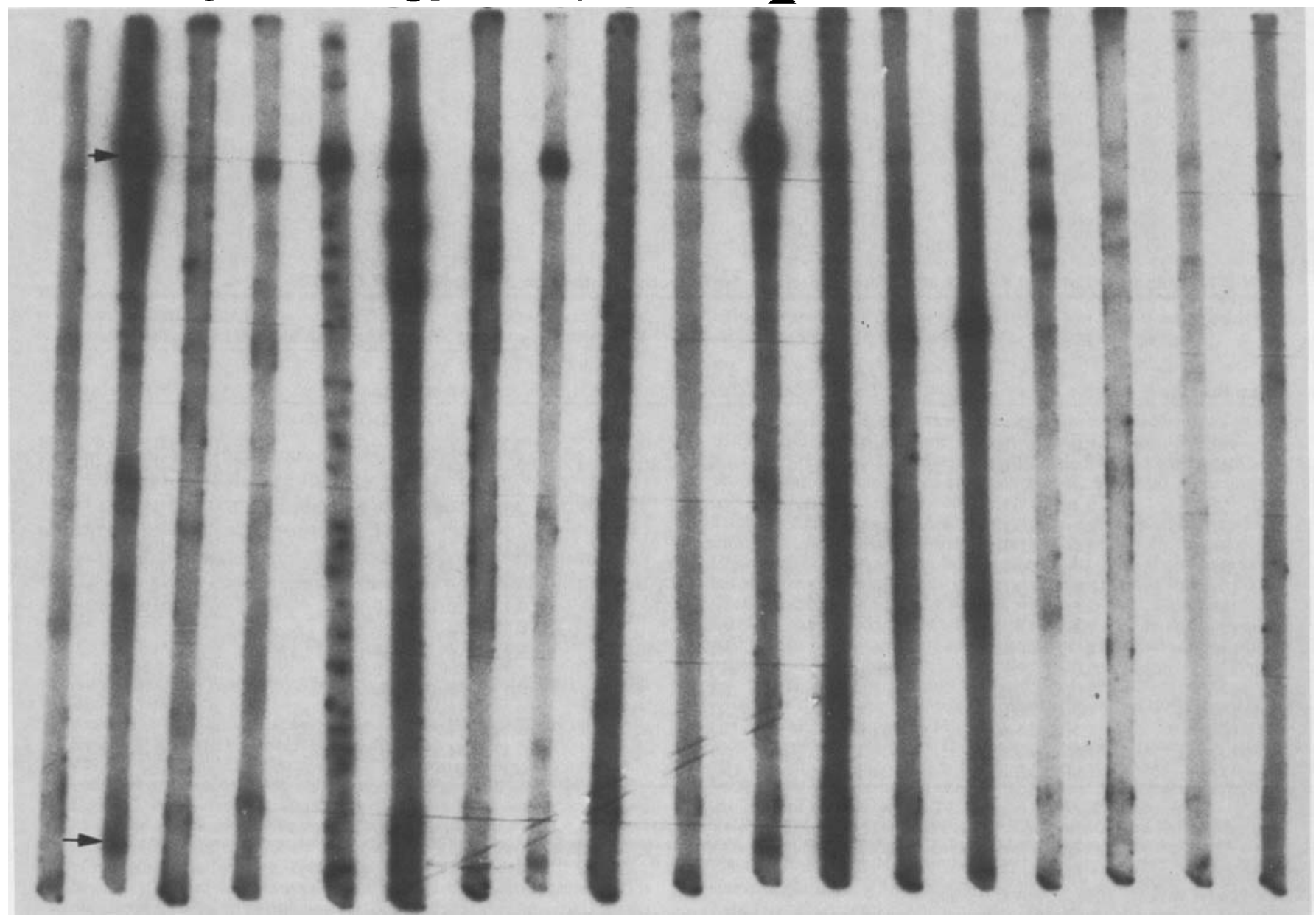

Fig. 2. Same as Figure 1, except that $I^{125}$-labeled protein $A$ was used as a detecting probe. 
respectively. Interestingly, most showed binding with a high molecular weight sperm antigen(s) with a $\mathrm{Rf}$ value of $0.18 \pm 0.02$ and an approximate molecular weight of 90,000 dalton. It is apparent from close comparisons that the relative intensity and the number of detectable antigens vary somewhat with different detecting probes. Such variations may be attributed to the differential affinity of protein A and antihuman IgG to different subclasses of human IgG that were present in patients' serum samples. Nevertheless, in most cases, both antihuman IgG and protein $\mathrm{A}$ did recognize similar sperm antigens that reacted with sperm antibodies in a given serum sample. The $\mathrm{Rf}$ values of all the detected human sperm antigens on nitrocellulose strips by this assay are listed in Table I for comparisons.

As clearly shown in Figures 1 and 2, sera 97, 106, 137, and 139 revealed a strong binding to additional sperm proteins of lower molecular weights. On the contrary, the control sera did not exhibit any significant binding between sera and sperm proteins on the strips, even at lower serum dilutions.

Also presented in Table I are the comparisons of results from different test procedures for serum antisperm antibodies. In addition to SDS gel/protein blot radioimmunobinding method, data for microplate radioimmunoassay and enzyme-linked immunoassay, data for the FranklinDukes, Isojima, and tray agglutination tests are also listed. ${ }^{7-10}$ It can be shown in this table that some disagreements exist among different test procedures. It is likely that each test procedure for sperm antibodies is sensitive only to certain types or aspects of antisperm antibodies in humans. However, with SDS gel/protein blot radioimmunobinding method, one is able to obtain direct infor- mation regarding the molecular size of sperm autoantigens that elicit sperm antibodies resulting in agglutination and/or complement-dependent immobilization of human spermatozoa. We believe that this sensitive assay procedure provides a unique tool for the identification as well as for subsequent isolations of these sperm autoantigens. The characterization of these specific sperm antigens may prove to be important during the investigation of the association of sperm antibodies with human infertility as well as their potential application in immunological contraception. ${ }^{6}$

\section{Analysis of Other Clinically Defined Serum Samples}

Additional serum samples from twenty-one infertile men and thirteen vasectomized patients ${ }^{2}$ were also analyzed by SDS gel/protein blot radioimmunobinding method. The serum samples from infertile men contained agglutinating antisperm antibodies of different titers as shown by the tray agglutination test ${ }^{15}$ (and A. C. Menge, unpublished data). The results of our analysis using $\mathrm{I}^{125}$-labeled protein A as detecting probe are presented in Figure 3 . The high molecular sperm antigen(s) with a similar $\mathrm{Rf}$ value of about 0.2 was also detected from strips that had been incubated with serum samples of some vasectomized patients (sera 22 to 34 ). Apparently, antibodies to this unique human autoantigen(s) were also produced in some vasectomized patients.

The results of this analysis seem to suggest that this high molecular weight antigen(s) in human spermatozoa may play an important role in sperm autoimmunity. Further testing of this hypothesis must await the purification and immunological characterization of this antigen(s).

TABLE I. Comparison of Test Results of Different Methods for Detecting Antisperm Antibodies of W.H.O. Bank Sera

SDS Gel/protein blot RIM(Rf Values)

\begin{tabular}{|c|c|c|c|c|c|c|}
\hline Serum Number & $\begin{array}{l}\text { MIA } \\
\text { Titer }\end{array}$ & $\begin{array}{l}\text { TAT } \\
\text { Titer }\end{array}$ & $\begin{array}{l}\text { F-D } \\
\text { Titer }\end{array}$ & $\begin{array}{l}\text { SIT } \\
\text { Titer }\end{array}$ & I $^{125}$-Antihuman IgG & $\mathrm{I}^{125}$-Protein A \\
\hline 38 & $2.9(\mathrm{E}) 4.7(\mathrm{R})$ & $64(\mathrm{HH})$ & - & - & $0.19^{*}, 0.37,0.70,0.95$ & $0.18^{*}, 0.37,0.67,0.95$ \\
\hline 48 & $2.4(E) 4.4(R)$ & - & $+1-$ & - & $\begin{array}{l}0.19 *, 0.26,0.36 \\
0.57,0.70,0.95\end{array}$ & 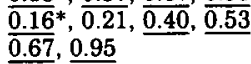 \\
\hline 52 & $2.4(E) 5.1(R)$ & - & - & - & $0.18 * 0.26,0.30,0.60$ & $0.18 * 0.58$ \\
\hline 71 & $2.1(\mathrm{E}) 6.0(\mathrm{R})$ & $32(\mathrm{TT})$ & - & - & $0.18 *, 0.26,0.37$ & $0.18^{*}, 0.40,0.91$ \\
\hline 96 & $2.2(\mathrm{E}) 4.0(\mathrm{R})$ & $8(\mathrm{TT})$ & - & - & $0.16^{*}, 0.33,0.68$ & $0.16 *, 0.95$ \\
\hline 97 & $2.4(\mathrm{E}) 5.6(\mathrm{R})$ & $128(\mathrm{TT})$ & - & 16 & $0.18 *, 0.30$ & $0.16^{*}, 0.24^{*}, 0.32^{*}$ \\
\hline 104 & $2.0(\mathrm{E}) 5.2(\mathrm{R})$ & $1024(\mathrm{TT})$ & - & - & $0.17,0.26,0.28$ & $0.17,0.27$ \\
\hline 106 & $2.3(\mathrm{E}) 4.6(\mathrm{R})$ & 256(TT,M) & + & 512 & $0.17,0.20,0.58^{*}, 0.72$ & $0.17 *, 0.60,0.95$ \\
\hline 109 & $1.9(\mathrm{E}) 3.3(\mathrm{R})$ & $256(\mathrm{M})$ & $+1-$ & 16 & $0.37,0.72$ & - \\
\hline 112 & $2.0(E) 4.0(R)$ & $64(\mathrm{TT})$ & NT & - & $0.17^{*}, 0.24$ & $0.18,0.68$ \\
\hline 119 & $2.0(\mathrm{E}) 6.2(\mathrm{R})$ & 2048(HH,M) & NT & $\ldots$ & $0.17 *, 0.80,0.90,0.95$ & $\overline{0.17}^{*}, 0.55$ \\
\hline 127 & $1.9(\mathrm{E}) 5.5(\mathrm{R})$ & $64(\mathrm{M})$ & NT & 8 & $0.17,0.20,0.28,0.56,0.72$ & $\overline{0.18}, 0.95$ \\
\hline 132 & $1.9(\mathrm{E}) 6.8(\mathrm{R})$ & - & NT & - & $0.37,0.73,0.95$ & $0.37,0.70$ \\
\hline 137 & $1.1(\mathrm{E}) 5.5(\mathrm{R})$ & $64(\mathrm{HH})$ & NT & 8 & $0.17 * 0.36 *, 0.44,0.72,0.95$ & $\overline{0.37}, \overline{0.70}$ \\
\hline 139 & $1.8(\mathrm{E}) 5.6(\mathrm{R})$ & $64(\mathrm{TT})$ & NT & 32 & $0.17,0.24,0.28,0.37,0.72$ & $0.18 * 0.24 * 0.37$ \\
\hline 142 & $1.6(\mathrm{E}) 4.9(\mathrm{R})$ & $128(\mathrm{TT})$ & NT & 32 & $0.32,0.67$ & $0.18,0.24,0.30$ \\
\hline
\end{tabular}

MIA $=$ Microplate immunoassay. TAT $=$ Tray agglutination test. F-D $=$ Franklin-Dukes test. SIT $=$ Sperm immobilization test. SDS gel/protein blot RIM $=$ Sodium dodecyl sulfate gel/protein radioimmunobinding method. $\mathrm{Rf}=$ Reference values. $\mathrm{E}=$ Microplate enzyme-linked immunoassay $($ ELISA). $\mathrm{R}=\mathrm{Microplate}$ radioimmunoassay. HH $=$ Headto-head agglutination. TT = Tail-to-tail agglutination. $M=$ Mixed type agglutination. NT = Not tested

* = Protein bands detected with high intensity and identified unambiguously.

$+=$ Positive. $-=$ Negative $+1-=$ Uncertain

MIA titers are expressed in ratios of radioactivity or optical density between the bank sera and the control at 1:20 serum dilutions.

Underlined reference values indicate the protein bands commonly detected by both $\mathrm{I}^{\mathbf{1 2 5}}$-labeled detecting probes. 


\section{PROTEIN A}

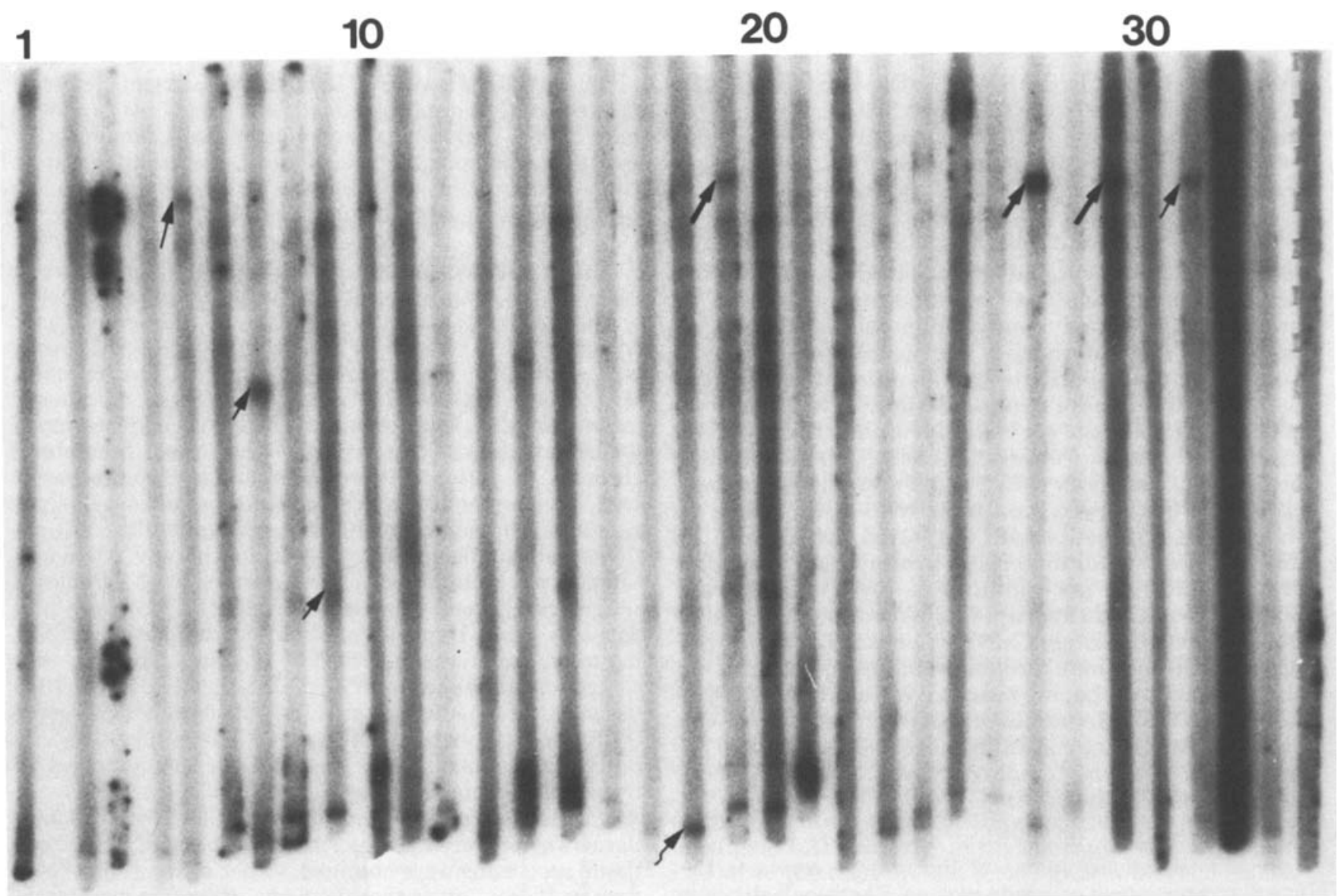

Fig. 3. Autoradiogram of the nitrocellulose strips of selected serum samples from the Andrology Laboratory in Ann Arbor. Michigan (University of Michigan), including those of the vasectomized patients (samples \#22 to \#341. Conditions of autoradiography and serum dilution are the same as Figure 1 , except that $\mathbf{I}^{125}$-labeled protein $\mathrm{A}$ was used a detecting probe. Unambiguously detected protein bands are indicated by arrows.

\section{ACKNOWLEDGMENT}

The standard serum samples from the Reference Bank of the World Health Organization were provided by Dr. T. Hjort of the Institute of Medical Microbiology, University of Aarhus, Aarhus, Denmark. The serum samples of vasectomized patients used in this study were the generous gift of Dr. Rudi Ansbacher, University of Michigan, Ann Arbor, Michigan.

\section{REFERENCES}

1. Ansbacher R. Vasectomy: Sperm antibodies. Fertil Steril. 1973; 24:788-792.

2. Ansbacher R. Humoral sperm antibodies: A 10-year follow-up of vasligated men. Fertil Steril. 1981; 36:222-224.

3. Freund J, Lipton MM, Thompson GE. Aspermatogenesis in guinea pig induced by testicular tissues and adjuvants. J Exp Med. 1953; 97:711-726.

4. Bishop DW, Carlson GL. Immunologically induced aspermatogenesis in guinea pig. Ann NY Acad Sci. 1965; 124:247-266.

5. Menge AC, Black CS. Effects of antisera on human sperm penetration of hamster zona-free ova. Fertil Steril. 1979; 32:214-218.

6. Menge AC. Clinical immunologic infertiligy, diagnostic measures, incidence of antisperm antibodies, fertility and mechanisms. In: Dhindsa
D, Schumacher GB, eds. Immunological Aspects of Infertility and Fertility Regulation. New York: Elsevier/North Holland, 1980:205-224.

7. Kibrick S, Belding DL, Merrill B. Methods for the detection of anti. bodies against mammalian spermatozoa. II. A gelatin agglutination test. Fertil Steril. 1952; 3:430-438.

8. Franklin RR, Dukes CD. Antispermatozoal antibody and unexplained infertility. Am J Obstet Gynecol. 1964; 89:6-9.

9. Isojima S, Li TS, Ashitaka Y. Immunolial analysis of spermimmobilizing factor found in sera of women with unexplained sterility. Am J Obstet Gynecol. 1968; 101:677-683.

10. Lee CY, Huang YS, Hu PC, Gomel V, Menge AC. Analysis of sperm antigens by sodium dodecyl sulfate gel/protein blot radioimmunobinding method. Anal Biochem. 1982; 123:14-22.

11. Lee CY, Huang YS, Huang $\mathrm{CH}$, Hu PC, Menge AC. Monoclonal antibodies to human sperm antigens. J Reprod Immunol. 1982; 4:173-183.

12. Greenwood FC, Hunter WM. The preparation of $I^{131}$-labelled human growth hormone of high specific radioactivity. Biochem J. 1963; 89:114-123.

13. Laemmli UK. Cleavage of structural proteins during the assembly of the head of bacteriophage T4. Nature. 1970; 227:680-685.

14. Voller A, Bidwell D, Bartlett A. The Enzyme-Linked Immunosorbent Assay (ELISA). Dynatech Laboratories, Inc, 1979:35-72.

15. Friberg J. A simple and sensitive micro-method for demonstration of sperm agglutinating antibodies in serum from infertile men and women. Acta Obstet Gynecol Scand [Suppl]. 1974; 36:43-50. 